\title{
THE GENUS VANDA (ORCHIDACEAE: AERIDINAE) IN THE PHILIPPINES: TWO NEW SPECIES AND A KEY TO THE SPECIES IN THE ARCHIPELAGO
}

\author{
MARTIN Motes \\ Reaseach Associate, Fairchild Tropical Botanic Garden, 10900 Old Cutler Road, Coral Gables, \\ Florida, U.S.A.・martinmotes@gmail.com
}

Abstract. Two Philippine Vanda species long confused with the Javanese species $V$. limbata and $V$. helvola are here described as V. mariae and $V$. cootesii. A key to the genus Vanda in the Philippines is provided.

KeY words: Java, new species, Philippines, Vanda

Subsequent to the seminal work of Eduardo Quisumbing (Valmayor 1981), a good deal of confusion has ensued in the identification of Philippine Vanda species. The recognition of $V$. ustii Golamco, Claustro \& de Mesa (Golamco et al. 2000) and V. barnesii W.E.Higgins \& Motes, as distinct species (Higgins \& Motes 2012) has contributed to clarify the taxonomy of the group. The recent description of $V$. mindanaoensis Motes, L.M.Gardiner \& D.L.Roberts (Motes et al. 2015) has resolved the identity of this species, which has long been misidentified. Two more Philippine species which have been ascribed to superficially similar Javanese species need to be described as species in their own right. Vanda cootesii and $V$. mariae are described here, and a key to the Philippine species is provided.

Including the two species described hereafter, the genus Vanda is represented in the Philippines by 12 species. These fall into four different sections. Section Ascocentrum (Schltr.) L.M.Gardiner has one Philippine species, V. aurantiaca (Schltr.) L.M.Gardiner ssp. philippinesis (Christenson) L.M.Gardiner, as does Section Dactylolobata W.Suarez \& Cootes, with V. mindanaoensis. Section Deltoglossa Christenson is represented by 5 species ( $V$. cootesii [described here], $V$. luzonica Loher ex Rolfe, V. mariae [also described in this paper], V. merrillii Ames \& Quisumb., and $V$. ustii). Section Lamellata is also represented by five species ( $V$. barnesii, $V$. javierae D.Tiu, V. lamellata Lindl., $V$. roebelingiana Rolfe, and $V$. sanderiana Rchb.f.). As would be expected of an archipelago, all but two of the species are endemic.

Vanda lamellata is the most cosmopolitan of any species in the genus, ranging as far north as
Taiwan, as far east as Ryukyu islands of Japan and the Mariana Islands and as far west as Borneo. The species distinct keeled lip doubtless makes it readily pollinated by some insect or group of insect species. The plants of the various forms exhibit quite varied plant architecture, ranging from the deeply V-shaped leaves of var. boxallii (Rchb.f.) Rchb.f. to the broad flat leaves of var. remediosa Ames \& Quisumb. Flowering seasons also vary. Most varieties are known to bloom throughout the year, but some are completely indeterminate, while var. boxallii is predominately a short day plant and transmits this quality to its hybrid progeny. The possibility exists that more precise DNA research will separate several species from this wide ranging and various species.

Vanda aurantiaca ssp. philippinesis, long mistakenly identified as Ascocentrum miniatum (Lindl.) Schltr. (an Indonesian species which ranges northward to Malaysia), is endemic to the Philippines, but $V$. aurantiaca ssp. aurantiaca occurs in Sulawesi.

Vanda limbata Blume has long been thought to occur in the Philippines. Jeffrey B. Comber, in his Orchids of Java, described the range of $V$. limbata as "also in the Philippines" (Comber 1990, Motes \& Roberts 2008). The present author's first encounter with the "Philippine $V$. limbata" occurred in the mid-eighties. The late Fred Fuchs had brought back plants labeled $V$. limbata from a cultivated source in Singapore. One of these plants was depicted as $V$. limbata "Singapore" in Vandas: Their Botany, History and Culture (Motes 1997). The numerous differences in plant architecture, inflorescence, and flower color were obvious, but the uncertainty of the true origins of the plants left open the possibility that the plants might 


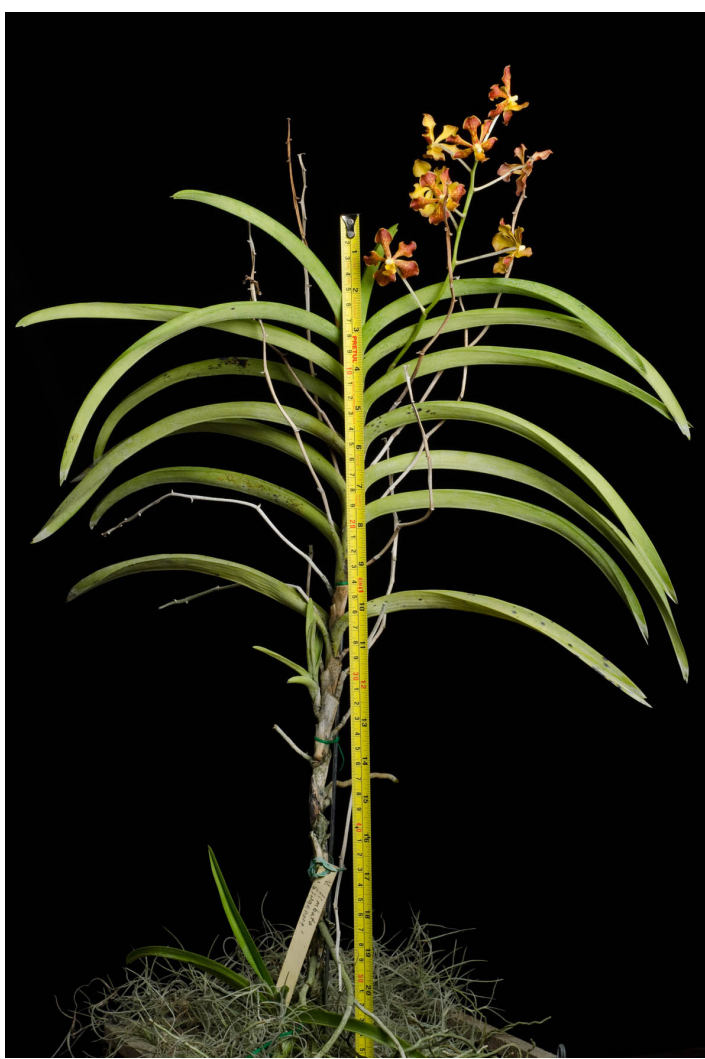

FiguRE 1. Vanda mariae. Note the leaves narrower and more deeply furrowed than those of $V$. limbata. Photograph by Greg Allikas.
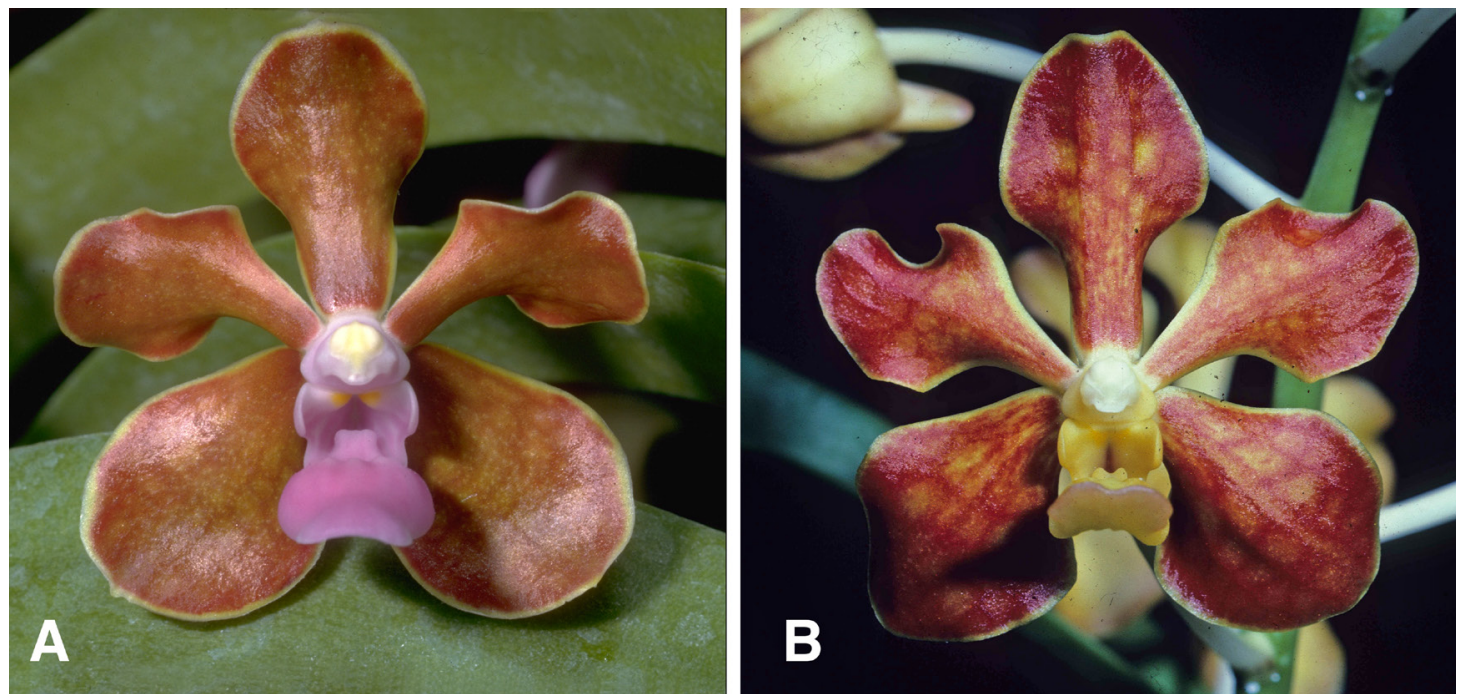

Figure 3. A. Vanda limbata from Java. The lavender lip, broad at the base and gently tapering, with a large callus, distinguishes this species from $V$. mariae. B. Vanda mariae differs from $V$. limbata by its narrow, straight lip with two small calli, as well as by its orange-red color. Photographs by Alan Hoffman. 
be of hybrid derivation. During a trip to Luzon last year I was able to observe several nearly identical plants in private collections. These corresponded with a number of pictures on the internet of the "Philippine $V$. limbata" or the "orange V. limbata" (Pagdato 2016, Shaun 2016). Although no one is certain of (or willing to reveal) the location of origin, plants periodically appear for sale in horticultural venues in the Philippines. The Philippine plants are of much smaller stature than $V$. limbata from Java, with harder and more deeply furrowed leaves (Fig. 1). The flowers, while superficially similar to those of V. limbata, are usually yellow, overlaid with reddish brown, as opposed to the solid deep chestnut brown of typical V. limbata (Figs. 2, 3A-B). Unlike the Javanese V. limbata, in which there is a barely discernible pattern of underlying tessellation, the sepals and petals of the Philippine plants are distinctly tessellated (Fig. 4). In $V$. limbata the violet mid-lobe is narrow and straight (Fig. 3A). In the Philippine plants the yellow overlaid with red midlobe is deltoid but rolled at the margins (Fig. 3B), making it somewhat resemble $V$. limbata's lip. Vanda limbata has a single prominent callus at the base of the mid-lobe and two small calli on the column foot at the entrance to the spur. In the Philippine plants there are two small calli at the base of the mid-lobe and the calli on the column foot are lacking. The mid-lobe of $V$. limbata is smooth while the mid-lobe of the Philippine flowers is adorned with three low ridges. Based on these ample differences, the Philippine plants are here described as:

\section{Vanda mariae Motes, sp. nov.}

TYPE: Philippines. Without locality, cult., May 2012, M. Motes 2 (holotype, FTG). Figs. 1-2, 3B, 4-5.

Similar to Vanda limbata Blume but distinguished by the yellow color with red brown tessellation of sepals and petals, and the yellow lip overlaid with red.

A climbing monopodial, epiphytic herb. 30$45 \mathrm{~cm}$ or more tall, $35-40 \mathrm{~cm}$ wide between leaf apices. Leaves glabrous, waxy, sessile, distichous, linear, 20-21 $\times 2.0-2.5 \mathrm{~cm}$, the margins entire, the apex praemorse. Inflorescence axillary, an erect, cylindrical raceme, loosely 6-11 flowered, $15-20 \mathrm{~cm}$ long. Flowers pale yellow strongly overlaid with red brown, with stronger red brown tessellation. 5.1-5.2 cm horizontally, 5.1-5.2 cm vertically. Dorsal sepal spathulate, clawed, yellow, tessellated with red brown distally, spotted red brown basally, the margins clear yellow, $2.8 \times 1.7 \mathrm{~cm}$. Lateral sepals spathulate, clawed, yellow heavily overlaid with red brown tessellations, the margins clear yellow, $2.9 \times 2.0$ $\mathrm{cm}$. Petals clawed, spathulate, obtuse, entire, yellow tessellated and spotted with red brown, the margins clear yellow, $2.9 \times 1.7 \mathrm{~cm}$. Labellum yellow suffused with red brown, three-lobed; midlobe deltoid, rolled longitudinally along the margins appearing narrowly pandurate in natural position, yellow suffused with red brown, with low longitudinal ridges and two small calli at base, $1.7 \times 0.6 \mathrm{~cm}$; lateral lobes lobes trapezoidal, yellow, $0.4 \times 0.3 \mathrm{~cm}$; spur slightly flattened, $0.5 \times 0.2 \mathrm{~cm}$. Column white, slightly thickened at base, $0.9 \times 0.2 \mathrm{~cm}$. Anther cap white, 0.2 x $0.2 \mathrm{~cm}$. Pollinia 2 , spherical, stiped.

Distribution: Philippines. No specific locality recorded (Cootes 2011).

Eponymy: Named for Mary Motes, noted for her long support of botanical and horticultural research.

Conservation Status: Data deficient.

Plants from the Philippines identified as $V$. helvola Blume have long been reported (Chan et al. 1994: 307). Plants more recently discovered on Mindanao have initially been identified as $V$. helvola. James Cootes identifies the species' locality as Cotabato where "It grows as an epiphyte at elevations of between 400 and 1500 metres" (Cootes 2011) The author obtained two plants of the species from Purification Orchids in the Philippines two years ago. These Philippine plants are of a much larger size than the Javanese $V$. helvola, with longer and narrower leaves (Fig. 6). The flowers, like the Javanese $V$. helvola (Fig. 7), are brown but tinged with green at the apices of the tepals (Fig. 8 ), whereas in $V$. helvola the color is uniform without the green apices and underlying stripes found in the Philippine plants. The lip of the Philippine plants is also superficially similar, with prominent appendages at the base of the mid-lobe but unlike the distinctly deltoid lip of $V$. helvola, the Mindanao plants have a narrowly pandurate mid-lobe darkest at the apex where $V$. helvola is light green (Roberts \& Motes 2009). The Mindanao plants are here described as: 

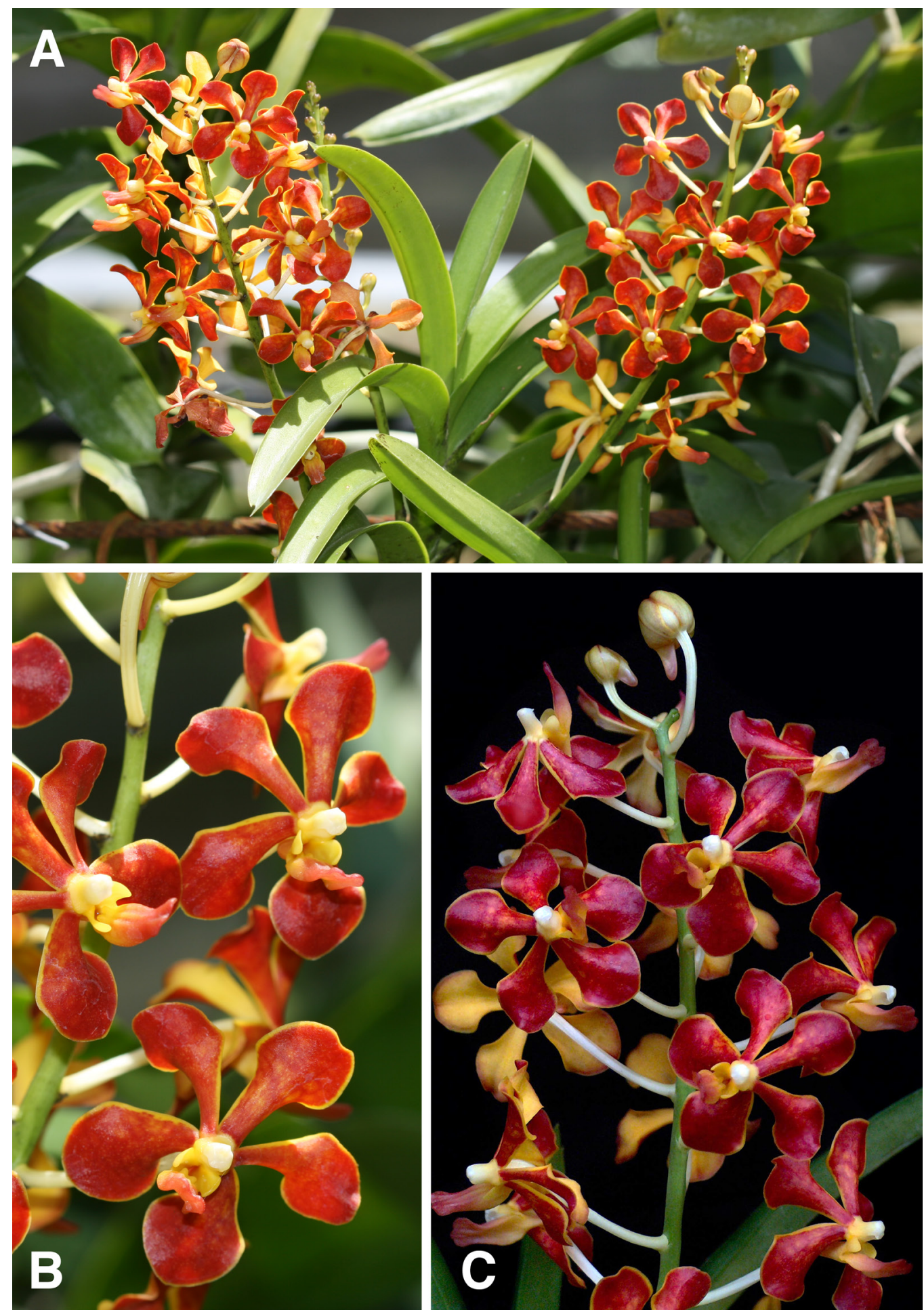

FiguRE 4. Vanda mariae occurs in various tones of red and orange. Photographs by Nelson Geraldino (A, B) and Rommel Arriola (C). 


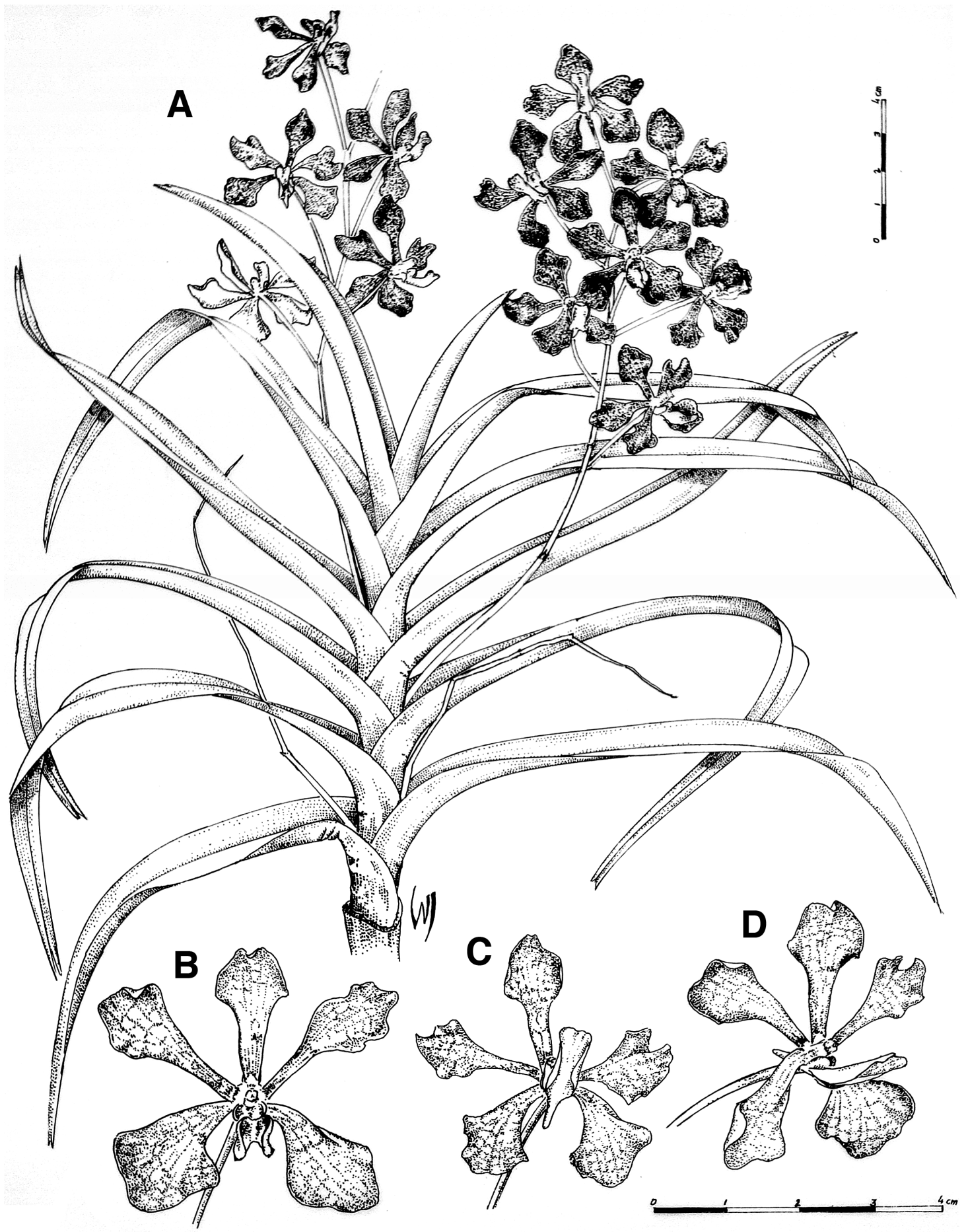

FiguRe 5. Vanda mariae Motes. A. Habit. B-D. Flower in frontal view, from below, and three quarters view. Drawing by Wes Jurgen based on the holotype. 


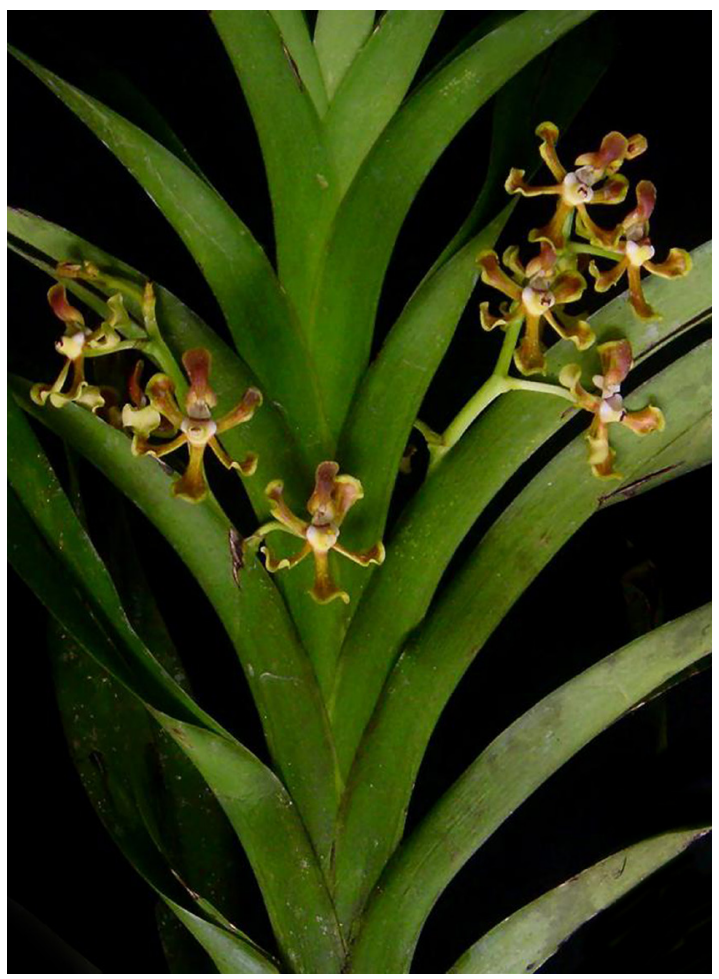

FIGURE 6. Vanda cootesii is a taller plant with narrower leaves than $V$. helvola. The flowers appear non-resupinate here because the plant flowered after a recent importation. Photograph by Greg Allikas.
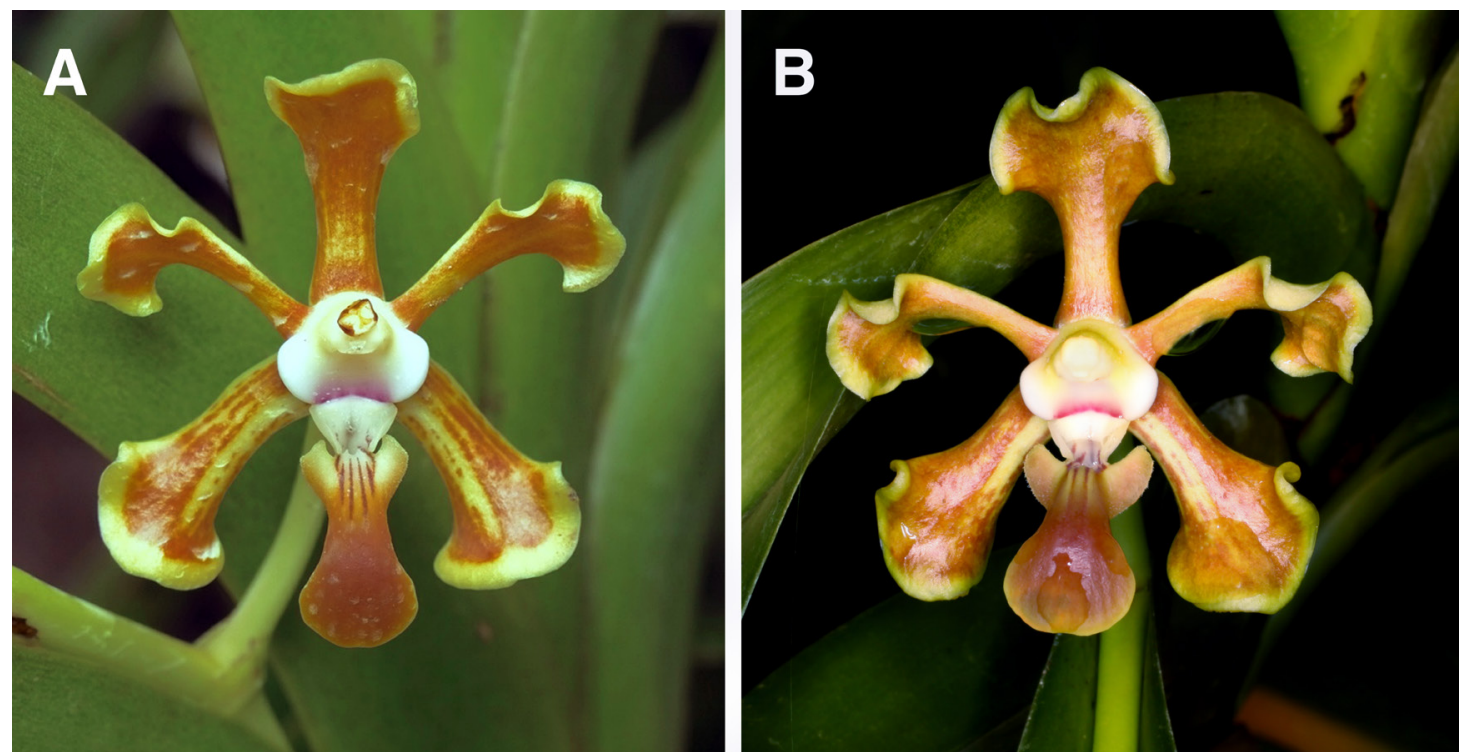

FIgURE 8. Vanda cootesii varies slightly in the proportion of yellow green to brown in the flowers. Photographs by Miguel de Leon (A) and Jim Cootes (B). 
Vanda cootesii Motes, sp. nov.

TYPE: Philippines. Mindanao: Cotabata, cult. May 2014, M. Motes 13 (holotype, FTG). Figs. 6, 8-9.

Similar to Vanda helvola Blume to which it bares superficial resemblance in color and lip shape. Distinguished by the green margins of sepals and petals and the narrow pandurate lip with flared base and the apex of the midlobe dark brown.

A climbing monopodial, epiphytic herb. 45-100 $\mathrm{cm}$ or more tall, $40-50 \mathrm{~cm}$ wide between leaf apices. Leaves glabrous, waxy, sessile, distichous, linear, $21-23 \times 3.3-3.5 \mathrm{~cm}$, the margins entire, the apex praemorse. Inflorescence axillary, a laxly 7-9 flowered raceme, $14-15 \mathrm{~cm}$ long. Flower yellow green with longitudinal ochre brown stripes, $3.5 \mathrm{~cm}$ horizontally, $4.0 \mathrm{~cm}$ vertically. Dorsal sepal spathulate, narrowly clawed, yellow green with ochre brown stripes coalescing to solid brown in the blade, with wavy green margins, $2.0 \times 1.2 \mathrm{~cm}$. Lateral sepals narrowly clawed, spathulate, yellow green with ochre brown stripes coalescing to solid brown in blade, the margins green, wavy, $2.0 \times 1.4 \mathrm{~cm}$. Petals clawed, spathulate, yellow green with ochre brown stripes coalescing to solid brown in blade, with wavy green margins, 1.9 $\times 0.9 \mathrm{~cm}$. Labellum yellow green overlaid with ochre brown, $1.0 \times 1.5 \mathrm{~cm}$, three-lobed; midlobe pandurate, narrower in the middle and broader at apex, the base narrowly flared, marked with very fine stripes of red brown; lateral lobes cream, oblong, curved inward at apex, $0.4 \times 0.6 \mathrm{~cm}$; spur oblong, flattened, $0.7 \mathrm{~cm}$ long. Column white, thickened at base, $0.3 \times 0.6 \mathrm{~cm}$. Anther cap white, $2 \times 2 \mathrm{~mm}$. Pollinia 2, spherical, stiped.

Distribution: Philippines. Cotabata on Mindanao, 400-1500 m (Cootes 2011).

Eponymy: Named for James Cootes, noted expert on Philippine orchid species.

Conservation Status: Data deficient.

\section{Key to the species of $V A N D A$ in the Philippines}

1. Flowers smaller than $2 \mathrm{~cm}$

V. aurantiaca spp. philippinesis

1a. Flowers larger that two $\mathrm{cm}$

2. Flowers with cylindrical columns

3. Midlobe of lip with distinct lobules

(Section Dactylolobatae): V. mindanaoensis

3a. Midlobe of lip without lobules

(Section Lamellata) 4

4. Flowers with longitudinal blades on mid-lobe of lip

(V. lamellata) 5

5. Flowers with distinctly two toned marking in lateral sepals

6. Leaves, V-shaped, flowers deep yellow

V. lamellata var. boxallii

6a. Leaves flat, flowers pale yellow nearly white

V. lamellata var. remediosa

5a. Flowers with mottled or indistinctly shaped brown markings

7. Lip yellow overlaid or striped with brown

V. lamellata var. lamellata

7a. Lip pink

V. lamellata var. calayana

4a. Flowers without longitudinal blades on lip

8. Flowers predominantly brown/red

V. roeblingiana

8a. Flowers predominantly white

9. Flowers without flared base to mid-lobe of lip

V. sanderiana

9a. Flowers with the base of lip midlobe flared

10. Side lobes of lip large, nearly solid red

V. barnesii

10a. Side lobes of lip small, spotted red

V. javierae

2a. Flowers with the column thickened at base

(Section Deltoglossa) 11

11. Flowers predominantly white or cream

12. Sepals and petals marked with red

V. luzonica

12a. Sepals and petals unmarked

V. ustii

11a. Flowers yellow, brown or red 


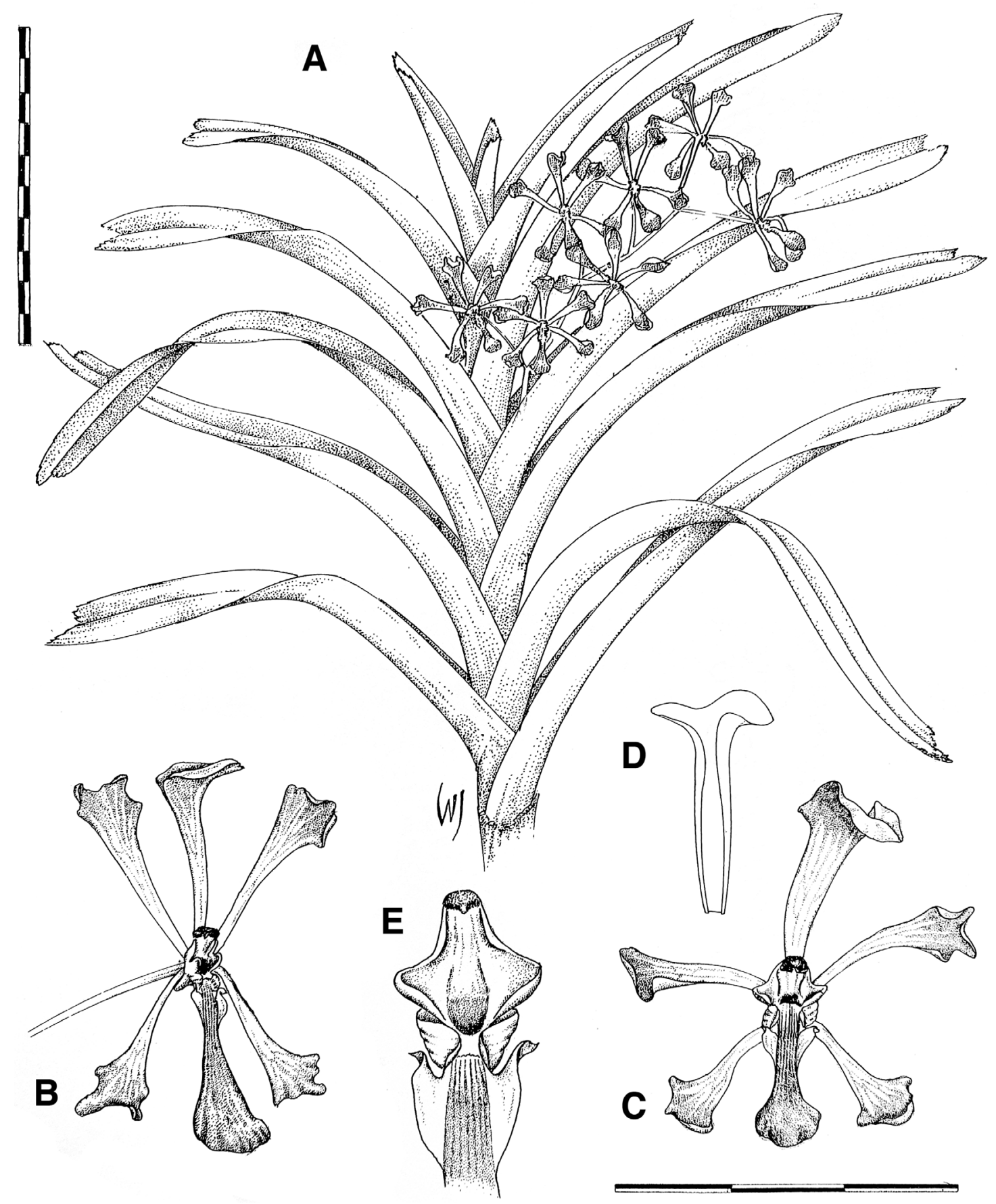

Figure 9. Vanda cootesii Motes. A. Habit. B-C. Flowers. D. Dorsal sepal, abaxial view. E. Base of the lip. Drawing by Wes Jurgen. 
13. Flowers tessellated

V. mariae

13a. Flowers spotted or concolorous lacking tessellation

14. Flowers solid red

V. merrillii var. rotorii

14a. Flowers yellow or yellow-brown

15

15. Flowers yellow spotted red

V. merrillii var. merrillii

15a. Flowers concolorous

16

16. Flowers golden yellow

V. merrillii var. immaculata

16a. Flowers concolor yellow brown tinged with green

V. cootesii

\section{LITERATURE CITED}

Chan, C. L., Lamb, A., Shim, P. S., \& Wood, J. J. (1994). Orchids of Borneo Vol. 1. Kota Kinabalu, Natural History Publications, Borneo and Royal Botanic Gardens, Kew.

Comber, J. B. (1990). Orchids of Java. Kew, Royal Botanic Gardens, Kew.

Cootes, J. E. (2011). Philippine native orchid species. Quezon City, Katha Publishing.

Golamco, A. S., Claustro (de), L. A. \& Mesa (de), P. (2000). Vanda ustii Golamco, Claustro et de Mesa sp.nov., a new orchid species from the Cordillera region of Luzon island, Philippines. Waling-Waling Review, 8(1), 9-15.

Higgins, W.E. \& Motes, M.R. (2012). A new Vanda (Orchidaceae) from the Philippines: Vanda barnesii. Orchid Digest, 76, 240-242.

Motes, M. (1997). Vandas: their botany, history and culture. Portland, OR, Timber Press Inc.

Motes, M., Gardiner, L. \& Roberts, D. (2015). Vanda Section Dactylolobata: a summary, two new Species and a key to identification. Orchid Digest,79, 96-102.

Motes, M. \& Roberts, D. L. (2008). Vanda furva: three centuries of confusion. Orchid Digest, 72, $174-178$.

Pagdato, M. A. C. (2016). Phyto Images. Orchidaceae. Vanda limbata. Retrieved at: http://phytoimages.siu.edu/imgs/ pelserpb/r/Orchidaceae_Vanda_limbata_52908.html, consulted December 2016.

Roberts, D. L. \& Motes, M. (2009). Vanda helvola, probably the most widespread species from the genus Vanda. Orchid Review, 117(1288), 196-199.

Shaun, L. (2016). PickAnOrchid. Vandaceous. Vanda limbata. Retrieved at: http://pickanorchid.com/vanda-limbata/, consulted December 2016.

Valmayor, H. L.(ed.)(1981). The complete writings of Dr. Eduardo Quisumbing on Philippine orchids. Manila, Eugenio Lopez Foundation, Inc. 
